\title{
Phytochemical and toxicological investigations of crude methanolic extracts, subsequent fractions and crude saponins of Isodon rugosus
}

Anwar Zeb, Abdul Sadiq*, Farhat Ullah, Sajjad Ahmad and Muhammad Ayaz

\begin{abstract}
Background: Isodon rugosus is used traditionally in the management of hypertension, rheumatism, tooth-ache and pyrexia. Present study was arranged to investigate I. rugosus for phytoconstituents, phytotoxic and cytotoxic activities to explore its toxicological, pharmacological potentials and to rationalize its ethnomedicinal uses. Briefly, qualitative phytochemical analysis of the plant extracts were carried out for the existence of alkaloids, flavonoids, saponins, oils, glycosides, anthraquinones, terpenoids, sterols and tannins. Plant crude methanolic extract (Ir.Cr), its subsequent fractions; $n$-hexane (Ir.Hex), chloroform (Ir.Chf), ethyl acetate (Ir.EtAc), aqueous (Ir.Aq) and saponins (Ir.Sp) in different concentrations were tested for phytotoxic and cytotoxic activities using radish seeds and brine shrimps (Artemia salina) respectively. The phytotoxic activity was determined by percent root length inhibition (RLI) and percent seeds germination inhibition (SGI) while the cytotoxicity was obtained with percent lethality of the brine shrimps.

Results: Ir.Cr was tested positive for the presence of alkaloids, glycosides, flavonoids, oils, terpenoids, saponins, tannins and anthraquinones. Among different fractions Ir.Sp, Ir.Chf, Ir.EtAc, and Ir.Cr were most effective causing $93.55,89.32,81.32$ and $58.68 \%$ inhibition of seeds in phytotoxicity assay, with $I C_{50}$ values of $0.1,0.1,0.1$ and $52 \mu \mathrm{g} / \mathrm{ml}$ respectively. Similarly, among all the tested samples, Ir.Sp exhibited the highest phytotoxic effect causing $91.33 \%$ root length inhibition with $\mathrm{IC}_{50}$ of $0.1 \mathrm{\mu g} / \mathrm{ml}$. Ir.Sp and Ir.Chf were most effective against brine shrimps showing 92.23 and $76.67 \%$ lethality with $L C_{50}$ values of 10 and $12 \mu \mathrm{g} / \mathrm{ml}$ respectively.

Conclusions: It may be inferred from the current investigations that I. rugosus contains different secondary metabolites and is a potential source for the isolation of natural anticancer and herbicidal drug molecules. Different fractions exhibited phytotoxic and cytotoxic activities, thus providing pharmacological basis for ethnomedicinal uses of this plant.
\end{abstract}

Keywords: Isodon rugosus, Cytotoxicity, Phytotoxicity, Brine shrimps

\section{Background}

The human environment and life are at constant risk of various complications [1]. Every individual on earth is in search of clean and healthy time. For the management of these major obstacles, a constant utilization of synthetic resources is the common inspiration [2]. Synthetic resources, being the most helpful tools to get rid of many complications are also a great cause of severe side effects [3-5]. So it is obvious that exploring the natural sources will be a great step toward the solution.

\footnotetext{
* Correspondence: sadiquom@yahoo.com

Department of Pharmacy, University of Malakand, Chakdara, Dir, Pakistan
}

According to a survey, medicinal plants cover $34 \%$ of the total plant species found in Pakistan [6]. In Pakistan at least six thousand flowering plants have been reported currently, among which 400-600 are of great medicinal importance [7]. Herbs have been employed in variety of medicinal and non-medicinal purposes, like flavoring, nutrition, spices, beverages, dyeing, repellents, cosmetics, perfumery, fuels and in many other industrial uses. Worldwide about $85 \%$ of primary health care medications are depend on natural sources [8]. Till the nineteenth century, man has discovered the great contribution 
of herbs in the management of almost every pharmacological disorder [9]. According to an estimation, up to 70,000 plant species are used ethno-medicinally worldwide [10]. Sidewise, there are several factors which influence the plant production, such as pest and weeds $[11,12]$.

Plants in the same family exhibit almost a similar pharmacological profile due to the same genome [13]. The plants in family labiateae or lamiaceae are explored for various pharmacological purposes, like analgesic, anthelmintic and antibacterial [14]. I. rugosus is used ethno-medicinally in the diseases of skin, ear, nose, throat and intestine [15]. Basically the Phytochemicals are broadly classified into two main categories, namely, primary constituents and secondary metabolites. Primary constituents includes proteins, amino acids,, common sugars and chlorophyll, whereas, secondary constituents include glycosides, alkaloids, phenolic compounds, flavonoids, saponins, essential oils, tannins and terpenoids [16]. Majority of phytochemicals contain important therapeutic activities and the plants thus find their medicinal importance due to presence of the respective phytochmical constituents. Furthermore, each pharmacological action demonstrated by a plant sample is attributed to the presence of secondary metabolites in it. In this regard possibly interesting class of molecules are the saponins, secondary plant metabolites composed of steroids or triterpenoid aglycone linked by glycosidic bonds with divergent biological activities [17]. Saponins having the ability to treat different disease conditions and have been used as antimicrobial, antidiabetic, cytotoxic, phytotoxic, antitumor, antioxidant, antispasmodic and as anthelmintic [18-21]. The crude saponins have been studied for their anticancer [22], anthelmintic [23] and insecticidal potentials [24].

Keeping in view the published importance of saponins and exploring the medicinal importance of I. rugosus, we have achieved its phytochemical studies along with phytotoxic and cytotoxic potentials.

\section{Results}

\section{Phytochemical analysis}

Ir.Cr was found to contain glycosides, alkaloids, tannins, terpenoids, flavonoids, saponins, anthraquinones and oils, while tested negative for the presence of sterols (Table 1).

\section{Phytotoxic assay}

The radish seed germination assay is of great importance for the phytotoxic activity of plant extract. The activity involves the measurement of the average root length and number of seeds inhibition in which the water serves as negative control. All the tested samples for phytotoxic potential of I. rugosus are summarized in Table 2 . In this study the Ir.Sp revealed significant phytotoxicity i.e., root length inhibition (RLI) $\left(\mathrm{IC}_{50}=0.1 \mu \mathrm{g} / \mathrm{ml}\right)$ and seeds germination inhibition (SGI) $\left(\mathrm{IC}_{50}=0.1 \mu \mathrm{g} / \mathrm{ml}\right)$. Among the fractions Ir.Chf exhibited highest phytotoxic activity i.e., $88.40 \pm 1.36,71.37 \pm 0.74$ and $66.51 \pm 0.39 \%\left(\mathrm{IC}_{50}=\right.$ $0.1 \mu \mathrm{g} / \mathrm{ml}) \mathrm{RLI}$ and $89.32 \pm 3.52,73.59 \pm 0.58$ and $68.37 \pm$ $0.62 \%\left(\mathrm{IC}_{50}=0.1 \mu \mathrm{g} / \mathrm{ml}\right)$ SGI at the concentration of 1000, 100 and $10 \mu \mathrm{g} / \mathrm{ml}$ respectively. Ir.EtAc demonstrated $80.40 \pm 0 . *+-68, \quad 74.55 \pm 0.51$ and $61.55 \pm 0.67 \%$ $\left(\mathrm{IC}_{50}=0.1 \mu \mathrm{g} / \mathrm{ml}\right) \mathrm{RLI}$ and 81.32 $\pm 5.8,71.55 \pm 0.65$ and $59.44 \pm 0.58 \%\left(\mathrm{IC}_{50}=0.1 \mu \mathrm{g} / \mathrm{ml}\right)$ SGI at 1000,100 and $10 \mu \mathrm{g} / \mathrm{ml}$ respectively. The Ir.Hex showed $80.40 \pm 0.68$, $77.33 \pm 0.64$ and $47.26 \pm 0.64 \% \quad\left(\mathrm{IC}_{50}=29 \mu \mathrm{g} / \mathrm{ml}\right) \quad \mathrm{RLI}$ and $56.00 \pm 4.6,47.26 \pm 0.61$ and $41.55 \pm 0.61 \%\left(\mathrm{IC}_{50}=\right.$ $410 \mu \mathrm{g} / \mathrm{ml})$ SGI at 1000,100 and $10 \mu \mathrm{g} / \mathrm{ml}$ respectively. The Ir.Cr and Ir.Aq revealed moderate phytotoxicity. The order of phytotoxicity for the given fractions were Ir.Chf $>$ Ir.EtAc $>$ Ir.Cr $>$ Ir.Hex $>$ Ir.Aq. From scientific verification it may be inferred that the other plants growing nearby I. rugosus may affected their growth. Majorly the phenolics are responsible for the phytotoxic action of plant [25].

\section{Cytotoxic assay}

The cytotoxic effect exhibited by Ir.Cr, Ir.Sp and resultant fractions of $I$. rugosus is presented in Table 3.

Table 1 Phytochemical constituents in crude extract of I. rugosus

\begin{tabular}{lll}
\hline S. no & Phytochemicals & Observations \\
\hline $\mathbf{1}$ & Alkaloids & Turbidity/precipitation \\
$\mathbf{2}$ & Flavonoids & Formation of yellow color which changed to colorless on acid addition \\
$\mathbf{4}$ & Saponins & Formation of frothing bubbles \\
$\mathbf{5}$ & Tannins & Formation of bluish-black color \\
$\mathbf{6}$ & Sterols & green to pink color was absent \\
$\mathbf{7}$ & Glycosides & Formation of red color precipitate \\
$\mathbf{8}$ & Anthraquinones & Formation of red, violet or pink color in aqueous layer \\
$\mathbf{9}$ & Terpenoids & Appearance of reddish brown color \\
\hline
\end{tabular}

Positive symbol (+) shows the presence while negative symbol (-) shows the absence of phytochemicals. 
Table 2 Phytotoxic effect of the crude extract of I. rugosus and its fractions against radish seeds

\begin{tabular}{|c|c|c|c|c|c|}
\hline Samples & $\begin{array}{l}\text { Conc. } \\
(\mu \mathrm{g} / \mathrm{ml})\end{array}$ & $\begin{array}{l}\text { Root length } \\
\text { inhibition\% } \\
\text { (mean } \pm \text { SEM) }\end{array}$ & $\begin{array}{l}\mathrm{IC} \mathrm{C}_{50} \\
(\mu \mathrm{g} / \mathrm{ml})\end{array}$ & $\begin{array}{l}\text { Seeds } \\
\text { inhibition\% } \\
\text { (mean } \pm \text { SEM) }\end{array}$ & $\begin{array}{l}\mathrm{IC} C_{50} \\
(\mu \mathrm{g} / \mathrm{ml})\end{array}$ \\
\hline \multirow[t]{3}{*}{ Ir.Cr } & 1000 & $72.00 \pm 0.20^{* * *}$ & \multirow[t]{3}{*}{25} & $58.68 \pm 3.52^{* * *}$ & \multirow[t]{3}{*}{52} \\
\hline & 100 & $63.15 \pm 0.91^{* * * *}$ & & $54.49 \pm 0.47^{* * *}$ & \\
\hline & 10 & $45.15 \pm 0.61^{* * *}$ & & $39.51 \pm 0.58^{* * *}$ & \\
\hline \multirow[t]{3}{*}{ Ir.Hex } & 1000 & $80.40 \pm 0.68^{* * *}$ & \multirow[t]{3}{*}{29} & $56.00 \pm 4.60^{* * *}$ & \multirow[t]{3}{*}{410} \\
\hline & 100 & $77.33 \pm 0.64^{* * *}$ & & $47.26 \pm 0.61^{* * *}$ & \\
\hline & 10 & $47.26 \pm 0.64^{* * *}$ & & $41.55 \pm 0.61^{* * *}$ & \\
\hline \multirow[t]{3}{*}{ Ir.Chf } & 1000 & $88.40 \pm 1.36^{*}$ & \multirow[t]{3}{*}{0.1} & $89.32 \pm 3.52^{\mathrm{ns}}$ & \multirow[t]{3}{*}{0.1} \\
\hline & 100 & $71.37 \pm 0.74^{* * *}$ & & $73.59 \pm 0.58^{\mathrm{ns}}$ & \\
\hline & 10 & $66.51 \pm 0.39^{*}$ & & $68.37 \pm 0.62^{n s}$ & \\
\hline \multirow[t]{3}{*}{ Ir.EtAc } & 1000 & $80.40 \pm 0.68^{* * *}$ & \multirow[t]{3}{*}{0.1} & $81.32 \pm 5.80^{\mathrm{ns}}$ & \multirow[t]{3}{*}{0.1} \\
\hline & 100 & $74.55 \pm 0.51^{* * *}$ & & $71.55 \pm 0.65^{*}$ & \\
\hline & 10 & $61.55 \pm 0.67^{* * *}$ & & $59.44 \pm 0.58^{* *}$ & \\
\hline \multirow[t]{3}{*}{ Ir.Aq } & 1000 & $40.40 \pm 0.44^{* * *}$ & \multirow[t]{3}{*}{1830} & $49.32 \pm 3.52^{* * *}$ & \multirow[t]{3}{*}{1045} \\
\hline & 100 & $33.67 \pm 0.55^{* * *}$ & & $41.55 \pm 0.64^{* * *}$ & \\
\hline & 10 & $30.55 \pm 0.64^{* * *}$ & & $33.62 \pm 0.61^{* * *}$ & \\
\hline \multirow[t]{3}{*}{ Ir.Sp } & 1000 & $91.33 \pm 0.62$ & \multirow[t]{3}{*}{0.1} & $93.55 \pm 0.64$ & \multirow[t]{3}{*}{0.1} \\
\hline & 100 & $84.52 \pm 0.48$ & & $81.44 \pm 0.67$ & \\
\hline & 10 & $69.51 \pm 0.79$ & & $66.59 \pm 0.52$ & \\
\hline $\begin{array}{l}\text { Negative } \\
\text { control }\end{array}$ & & - & & - & \\
\hline
\end{tabular}

Results expressed as average seeds inhibition and Inhibition of root length (mean $\pm \mathrm{SEM} \mathrm{n}=3$ ) and $\mathrm{IC}_{50}$. Values significantly different as compared to Standard drug; ${ }^{*} P<0.05$, ${ }^{* *} P<0.01$, ***P $<0.001$.

Lethality was highest at the concentration of $1000 \mu \mathrm{g} / \mathrm{ml}$ while low at the minimum concentration of each fraction. The Ir.Sp showed highest cytotoxic activity against brine shrimps i.e., $92.23 \pm 1.1,66.67 \pm 1.9$ and $52.23 \pm$ $1.1 \%$ brine shrimps lethality at the concentration of 1000,100 and $10 \mu \mathrm{g} / \mathrm{ml}$ respectively with the $\mathrm{LC}_{50}$ of $10 \mu \mathrm{g} / \mathrm{ml}$. Ir.Chf showed $(76.67 \pm 3.3,62.23 \pm 2.9$ and $48.90 \pm 1.1) \%$ cytotoxic effect at the concentration of $1000,100,10 \mu \mathrm{g} / \mathrm{ml}$ respectively with the $\mathrm{LC}_{50}$ of $12 \mu \mathrm{g} / \mathrm{ml}$. The Ir.EtAc also showed almost a similar cytotoxicity $(74.43 \pm 2.2,57.77 \pm 2.2$ and $43.33 \pm 1.9) \%$ at the concentration of $1000,100,10 \mu \mathrm{g} / \mathrm{ml} \mathrm{respec-}$ tively with the $\mathrm{LC}_{50}$ of $315 \mu \mathrm{g} / \mathrm{ml}$. The Ir.Aq also showed slightly lower cytotoxicity $(65.57 \pm 1.1,53.33 \pm$ 1.9 and $42.23 \pm 1.1) \%$ at the concentration of 1000,100 , $10 \mu \mathrm{g} / \mathrm{ml}$ respectively with the $\mathrm{LC}_{50}$ of $60 \mu \mathrm{g} / \mathrm{ml}$. The cytotoxic profile of Ir.Hex and Ir.Cr were lower compared to other fractions. The $\mathrm{LC}_{50}$ calculated were 10 , 12, 60, 120, 220 and $315 \mu \mathrm{g} / \mathrm{ml}$ for Ir.Sp, Ir.Chf, Ir.Aq, Ir.Hex, Ir.Cr and Ir.EtAc respectively. The order of cytotoxic activity were Ir.Sp $>$ Ir.Chf $>$ Ir.EtAc $>$ Ir.Aq $>$ Ir. Hex > Ir.Cr.
Table 3 Concentration dependent cytotoxic effect of the Ir.Cr extract of $I$. rugosus and its fractions against Artemia salina

\begin{tabular}{|c|c|c|c|c|}
\hline Extracts & $\begin{array}{l}\text { Total } \\
\text { treated }\end{array}$ & $\begin{array}{l}\text { Dose } \\
(\mu \mathrm{g} / \mathrm{ml})\end{array}$ & $\begin{array}{l}\% \text { Lethality } \\
\text { (mean } \pm \text { SEM) }\end{array}$ & $\begin{array}{l}\mathrm{LC}_{50} \\
(\mu \mathrm{g} / \mathrm{ml})\end{array}$ \\
\hline \multirow[t]{3}{*}{$\mathrm{Ir} . \mathrm{Cr}$} & 30 & 1000 & $71.10 \pm 1.1^{* * *}$ & 220 \\
\hline & & 100 & $46.67 \pm 3.3^{* * *}$ & \\
\hline & & 10 & $37.77 \pm 1.1^{* * *}$ & \\
\hline \multirow[t]{3}{*}{ Ir.Hex } & 30 & 1000 & $62.23 \pm 2.9^{* * *}$ & 120 \\
\hline & & 100 & $48.90 \pm 1.1^{* * *}$ & \\
\hline & & 10 & $40.00 \pm 1.9^{* * *}$ & \\
\hline \multirow[t]{3}{*}{ Ir.Chf } & 30 & 1000 & $76.67 \pm 3.3^{* * *}$ & 12 \\
\hline & & 100 & $62.23 \pm 2.9^{\mathrm{ns}}$ & \\
\hline & & 10 & $48.90 \pm 1.1^{\mathrm{ns}}$ & \\
\hline \multirow[t]{3}{*}{ Ir.EtAc } & 30 & 1000 & $74.43 \pm 2.2^{* * *}$ & 315 \\
\hline & & 100 & $57.77 \pm 2.2^{*}$ & \\
\hline & & 10 & $43.33 \pm 1.9^{*}$ & \\
\hline \multirow[t]{3}{*}{ Ir.Aq } & 30 & 1000 & $65.57 \pm 1.1^{* * *}$ & 60 \\
\hline & & 100 & $53.33 \pm 1.9^{* * *}$ & \\
\hline & & 10 & $42.23 \pm 1.1^{* *}$ & \\
\hline \multirow[t]{3}{*}{ Ir.Sp } & 30 & 1000 & $92.23 \pm 1.1$ & 10 \\
\hline & & 100 & $66.67 \pm 1.9$ & \\
\hline & & 10 & $52.23 \pm 1.1$ & \\
\hline
\end{tabular}

Standard drug; Etoposide, $\mathrm{LC}_{50}=9.8 \mu \mathrm{g} / \mathrm{ml}$. Values represents \% lethality and are expressed as mean $\pm \mathrm{SEM}$; ${ }^{*} \mathrm{P}<0.05$, ${ }^{* *} \mathrm{P}<0.01$, ${ }^{* * *} \mathrm{P}<0.001$.

\section{Discussion}

Cytotoxic activity is one of the prominent assay to develop novel anticancer drug candidates in different plants samples [26]. In the present study, I. rugosus is investigated for the determination of its anticancer potential against Artemia salina. The order of brine shrimps lethality is crude Ir.Sp $>$ Ir.Chf $>$ Ir.EtAc $>$ Ir.Aq $>$ Ir.Hex $>$ Ir.Cr. The cytotoxic effect of Ir.Sp and Ir.Chf were the most prominent. The high lethality of these plant samples showed that substances responsible for the cytotoxic effect are present in high amount in crude Ir.Sp and Ir.Chf fraction. As reported earlier that a positive co-relation exists between the brine shrimp lethality assay and human nasopharyngeal carcinoma (KB cell line) [27], so this method was employed for the determination of possible antineoplastic activity.

The phytotoxic activity of $I$. rugosus was carried out by employing radish seeds. The radish root length inhibition and seeds germination inhibition is actually due to phytotoxic effect of I. rugosus. The radish seeds growth inhibitin was highest for Ir.Chf fraction while lowest for the Ir.Aq as shown in the Table 2. Comparatively, the Ir.EtAc fraction showed low phytotoxicity as compared to Ir.Chf fraction. The other fractions also showed moderate phytotoxic effect which was comparatively low from that of Ir.Chf and Ir.EtAc. It is deduced from the 
results that the Ir.Chf and Ir.EtAc fractions of I. rugosus contain high amount of that constituents which are responsible for phytotoxic effect. Hence, it is deduced that constituents of the plant with herbicidal action are highly concentrated in Ir.Chf fraction.

Weeds play an important role in low production of crops. Huge economic loss in agriculture is reported each year due to harmful effects of weeds. Different techniques and chemicals are used to eliminate the harmful effects of these weed [28]. But there application is limited due to their other health hazard such as food toxicity and economical factors [29]. Hence alternative factors should be considered for removing these unwanted effects, which may be economical and having minimum harmful effects. The natural herbicides are being investigated in plants to get rid of the delayed hazardous effects of synthetic herbicides [30]. The Natural herbicides are preferred over chemical agents due to safety profile and low cost.

The Ir.Sp obtained from I. rugosus are assayed for the cytotoxic activity because saponins are reported to have anticancer action [31]. Saponins are the active constituent verified by many researchers for its anticancer potentials applying antitumor activity using potato model [32]. The brine shrimps lethality assay has also been conducted on Ir.Sp and have been resulted in promising lethality and hence proved to have cytotoxic activity [33]. The results of this activity reveal that constituents responsible for cytotoxic and phytotoxic effect of I. rugosus may be a significant source of natural herbicides for weeds to enhance the crops production rate in the field of agriculture.

\section{Conclusion}

This study reveals that I. rugosus contain secondary metabolites like; glycosides, alkaloids, saponins, tannins, flavonoids, terpenoids and anthraquinones. The plant crude extract, its subsequent fractions and crude saponins exhibited concentration dependent phytotoxic and cytotoxic actions which warrant isolation and characterization of novel and cost-effective compounds responsible for such valuable activities.

\section{Methods}

\section{Collection and extraction}

The plant was collected from Dir (KPK), Pakistan in the month of June. The plant name was confirmed at the Department of Botany, Shaheed Benazir Bhuto University Dir (KPK), Pakistan. The plant sample was kept in the herbarium of the same university with voucher number (1016AZ). The fresh aerial parts of plant were cleaned with distilled water and kept at room temperature for drying. After shade drying, the plant was grinded to coarse powder with the help of cutter mill. The powdered material $(8 \mathrm{~kg})$ was kept for maceration in 30 liters of $80 \%$ methanol with daily base occasional shaking for 22 days. It was then filtered and concentrated under reduced pressure using rotary evaporator at $40^{\circ} \mathrm{C}$. Finally, keeping the concentrated sample in water bath a semisolid crude extract was obtained with weight of $300 \mathrm{~g}$ [34].

\section{Fractionation}

The Ir.Cr extract was suspended in $500 \mathrm{ml}$ of distilled water and transferred into a separating funnel followed by the addition of an equal amount of $n$-hexane. Shake it vigorously and then kept for a while to separate the two layers. Both the layers were separated. Similarly, the fractionation was carried out by successive solventsolvent extraction with increasing polarity of the solvent. Each separated fraction was concentrated individually under reduced pressure using rotary evaporator. The fractions obtained were Ir.Hex 22 g, Ir.Chf 35 g, Ir.EtAc $80 \mathrm{~g}$ and Ir.Aq fraction of $120 \mathrm{~g}$.

\section{Extraction of crude Saponins}

To the pulverized plant sample $(20 \mathrm{~g})$ was added $100 \mathrm{ml}$ of $20 \%$ ethanol and kept in water bath for $4 \mathrm{~h}$ at $55^{\circ} \mathrm{C}$. The sample was filtered and extracted again with $200 \mathrm{ml}$ of $20 \%$ ethanol. Then by keeping it in water bath for some time, the volume dropped down to $40 \mathrm{ml}$. The sample was then transferred into a separating funnel and added $20 \mathrm{ml}$ diethyl ether to it with vigorous shaking. Both the diethyl ether and aqueous layers were separated. The aqueous layer was mixed with $60 \mathrm{ml}$ of $n$-butanol and separated by using a separating funnel. The $n$-butanol extract was washed with $10 \mathrm{ml}$ of $5 \%$ brine solution. The final volume was concentrated in a water bath and then transferred into a beaker. The sample was kept in an oven to get dried Ir.Sp weighing $1.1 \mathrm{~g}$ [35].

\section{Phytochemical investigation}

Qualitative phytochemical analysis of the plant extracts was carried out for the existence of glycosides, flavonoids, saponins, alkaloids, anthraquinones, terpenoids, sterols and tannins using the reported procedures [36]. For the detection of glycosides the plant extracts were hydrolyzed with $\mathrm{HCl}$ followed by neutralization with $\mathrm{NAOH}$. Few drops of Fehling's solution were added to the preparation and determined by the presence of red precipitates. The alkaloids were determined by using Dragendorff's reagent. For the detection of terpenoids and sterols the samples were treated with petroleum ether followed by extraction with chloroform. The appearance of reddish brown color for terpenoids and green to pink color for sterols was noted after treatment of chloroform layer with acetic anhydride and concentrated $\mathrm{HCl}$ in series. Anthraquinones were determined by the process of dissolving the extract in $1 \%$ of $\mathrm{HCl}$, then benzene and finally mixing with 
$\mathrm{NH}_{4} \mathrm{OH}$. The presence of anthraquinones was observed by appearance of pink, red or violet color.

The Presence of saponins was detected by the formation of froth bubbles in a beaker upon vigorous shaking using diluted samples.

\section{Phytotoxicity (radish seeds) assay}

The stock solution of each extract was prepared according the reported procedure [37]. A specific quantity, i.e. $50 \mathrm{mg}$ of each extract was dissolved in $5 \mathrm{ml}$ of methanol and $5 \mathrm{ml}$ of $n$-hexane respectively in a beaker to obtain concentration of $10,000 \mu \mathrm{g} / \mathrm{ml}$. Proper size filter papers (Whatman \#1) were kept in the petri plates. The solution containing plant extract was added to the petri dishes. By keeping in laminar flow for a while the solvent get evaporated from the petri plates. Each petri dish was diluted with $5 \mathrm{ml}$ of distilled water. Methanol, $n$-hexane and distilled water were used as control group. The seeds were sterilized with $0.1 \%$ mercuric chloride solution. Twenty five radish seeds were placed in each petri plate. All the petri plates containing the seeds were kept in incubator for five days at $25^{\circ} \mathrm{C}$. The root length and number of seeds germination inhibition were measured and counted. All the tests were performed in triplicate.

\section{Cytotoxicity (Brine shrimps lethality) assay}

The cytotoxic effect against Artemia salina (brine shrimp eggs) of the Ir.Cr and various fractions (Ir.Hex, Ir.Chf, Ir.EtAc, Ir.Aq) and Ir.Sp were carried following the reported procedure [38].

Brine solution was prepared by dissolving $38 \mathrm{~g}$ of sodium chloride in double distilled water. The brine solution prepared was simulated sea water. A tray having dimensions of $22 \times 32 \mathrm{~cm}$ was used in which a partition was created by a perforated plate. One side of the tray was covered by aluminum foil in which $50 \mathrm{mg}$ Artemia salina eggs were sprinkled and the other side was kept as such to be the place for newly hatched brine shrimps larvae. The tray was kept in incubator at $37^{\circ} \mathrm{C}$ for hatching purpose. After $24 \mathrm{~h}$ when the larvae got hatched, it was attracted from dark side using torch and collected using a Pasteur pipette. 30 larvae were put in different vials. Three dilutions of the solution were made by dissolving $20 \mathrm{mg}$ of the test sample in $2 \mathrm{ml}$ of organic solvents and then by transferring 5, 50 and $500 \mu \mathrm{l}$ of the stock solution into three different vials making 10, 100 and $1000 \mu \mathrm{g} / \mathrm{ml}$ concentrations respectively. To each vial sea water was added to adjust the volume $5 \mathrm{ml}$. Etoposide was used as positive control while for negative control sea water was used. The brine shrimps were kept in the vials for $24 \mathrm{~h}$ under light at $25^{\circ} \mathrm{C}$. After $24 \mathrm{~h}$, the number of brine shrimps alive and dead was counted in each vial using magnifying glass. The data was recorded in triplicate with the determination of $\mathrm{LC}_{50}$.

\section{Statistical analysis}

Each experiment was performed in replicates and values were expressed as mean \pm SEM. Two way ANOVA followed by multiple comparison Bonferroni's test were used to compare control group with the tested groups. The $\mathrm{P}$ values less than 0.05 were considered as statistically significant. $\mathrm{IC}_{50}$ values were calculated by a linear regression analysis among the percent inhibition against the extract concentrations via Microsoft Office Excel 2007 program.

\section{Competing interests}

The authors declare that they have no competing interests.

\section{Authors' contributions}

AZ and SA carried out experimental work, data collection and evaluation, literature search and manuscript preparation under the supervision of AS. MA, AS and FU refined the manuscript for publication. All authors read and approved the final manuscript for publication.

\section{Acknowledgements}

The author is grateful to Department of Pharmacy for the kind provision of research laboratories for conduction of these activities.

\section{Funding}

This research received no specific grant from any funding agency in the public, commercial, or not-for-profit sectors.

Received: 28 August 2014 Accepted: 28 October 2014

Published: 6 November 2014

\section{References}

1. Frumkin $\mathrm{H}$ : Beyond toxicity: human health and the natural environment. Am J Prev Med 2001, 20(3):234-240.

2. Ames BN, Profet M, Gold LS: Nature's chemicals and synthetic chemicals: comparative toxicology. Proc Nat Acad Sci 1990, 87(19):7782-7786.

3. Azmi MA, Naqvi S, Azmi MA, Aslam M: Effect of pesticide residues on health and different enzyme levels in the blood of farm workers from Gadap (rural area) Karachi-Pakistan. Chemosphere 2006, 64(10):1739-1744.

4. Yousef M, Salem M, Ibrahim H, Helmi S, Seehy M, Bertheussen K: Toxic effects of carbofuran and glyphosate on semen characteristics in rabbits. J Environ Sci Health Part B 1995, 30(4):513-534.

5. Pakulska D, Czerczak S: Hazardous effects of arsine: a short review. International J Occup Med Environ Health 2006, 19(1):36-44.

6. Sher H, Elyemeni M, Sher H, Hussain K: Ethnobotanical and Economic Observations of Some Plant Resources from the Northern Parts of Pakistan. Ethnobot Res Appl 2011, 9:27-41.

7. Khan S, Khan GM: In vitro antifungal activity of Rhazya stricta. Pak J Pharm Sci 2007, 20(4):279-284.

8. Abbasi AM, Khan M, Ahmad M, Zafar M, Jahan S, Sultana S: Ethnopharmacological application of medicinal plants to cure skin diseases and in folk cosmetics among the tribal communities of North-West Frontier Province, Pakistan. J Ethnopharmacol 2010, 128(2):322-335.

9. Plummer SM, Hill KA, Festing MF, Steward WP, Gescher AJ, Sharma RA: Clinical development of leukocyte cyclooxygenase 2 activity as a systemic biomarker for cancer chemopreventive agents. Cancer Epidemiol Biomarkers Prev 2001, 10(12):1295-1299.

10. Haq F, Ahmad H, Ullah R, labal Z: Species Diversity and Ethno Botanical Classes of the Flora of Allai Valley District Battagram Pakistan. Int J Plant Res 2012, 2(4):111-123.

11. Zehnder G, Gurr GM, Kühne S, Wade MR, Wratten SD, Wyss E: Arthropod pest management in organic crops. Annu Rev Entomol 2007, 52:57-80.

12. Jan G, Khan MA, Gul F, Ahmad M, Jan M, Zafar M: Ethnobotanical study of common weeds of Dir Kohistan valley, Khyber Pakhtoonkhwa, Pakistan. Pak J Weed Sci Res 2010, 16(1):81-88.

13. Pichersky E, Gang DR: Genetics and biochemistry of secondary metabolites in plants: an evolutionary perspective. Trends Plant Sci 2000, 5(10):439-445.

14. Naghibi F, Mosaddegh M, Mohammadi Motamed M, Ghorbani A: Labiatae family in folk medicine in Iran: from ethnobotany to pharmacology. Iranian J Pharm Res 2005, 2:63-79. 
15. Adnan M, Begum S, Latif A, Tareen AM, Lee L: Medicinal plants and their uses in selected temperate zones of Pakistani Hindukush-Himalaya. J Med Plants Res 2012, 6(24):4113-4127.

16. Krishnaiah D, Devi T, Bono A, Sarbatly R: Studies on phytochemical constituents of six Malaysian medicinal plants. J Med Plants Res 2009, 3(2):067-072.

17. Francis $G$, Kerem Z, Makkar HP, Becker K: The biological action of saponins in animal systems: a review. Br J Nutr 2002, 88(06):587-605.

18. Yuan C-S, Wang C-Z, Wicks SM, Qi L-W: Chemical and pharmacological studies of saponins with a focus on American ginseng. J Ginseng Res 2010, 34(3):160.

19. LV X, Qiu S, Sun X, Li Z: Preliminary Study on the Capability of Antioxidation and Scavenging Free Radicals of Sasanqua saponins. Sci Food 2005, 11:86-90.

20. Seth R, Sarin R: Analysis of the Phytochemical Content and Anti-microbial Activity of Jatropha gossypifolia L. Arch App/ Sci Res 2010, 2(5):285-291.

21. Pal D, Sannigrahi S, Mazumder UK: Analgesic and anticonvulsant effects of saponin isolated from the leaves of Clerodendrum infortunatum Linn. in mice. Ind J Exp Biol 2009, 47(9):743.

22. Man S, Gao W, Zhang Y, Huang L, Liu C: Chemical study and medical application of saponins as anti-cancer agents. Fitoterapia 2010, 81(7):703-714

23. Wang G-X, Jiang D-X, Li J, Han J, Liu Y-T, Liu X-L: Anthelmintic activity of steroidal saponins from Dioscorea zingiberensis $\mathrm{CH}$ Wright against Dactylogyrus intermedius (Monogenea) in goldfish (Carassius auratus). Parasitol Res 2010, 107(6):1365-1371.

24. De Geyter E, Geelen D, Smagghe G: First results on the insecticidal action of saponins. Commu Agric Appl Biol Sci 2007, 72(3):645.

25. Inderjit: Plant phenolics in allelopathy. The Bot Rev 1996, 62(2):186-202.

26. Karadeniz B, Ulker Z, Alpsoy L: Genotoxic and cytotoxic effects of storax in vitro. Toxicol Ind Health 2013, 29(2):181-186.

27. Mannan A, Inayatullah S, Akhtar MZ, Qayyum M, Mirza B: Biological evaluation of wild thyme (Thymus serpyllum). Pharm Biol 2009, 47(7):628-633.

28. Louda SM, Kendall D, Connor J, Simberloff D: Ecological effects of an insect introduced for the biological control of weeds. Science 1997, 277(5329):1088-1090.

29. Khuda F, lqbal Z, Khan A, Nasir F, Muhammad N, Khan JA, Khan MS: Metal analysis, phytotoxic, insecticidal and cytotoxic activities of selected medicinal plants of Khyber Pakhtunkhwa. Pak J Pharm Sci 2012, 25(1):51-58.

30. Sharp DS, Eskenazi B, Harrison R, Callas P, Smith AH: Delayed health hazards of pesticide exposure. Annual Rev Public Health 1986, 7(1):441-471.

31. Kerwin S: Soy saponins and the anticancer effects of soybeans and soy-based foods. Curr Med Chem-Anti-Cancer Agents 2004, 4(3):263-272.

32. Shao Y, Chin C-K, Ho C-T, Ma W, Garrison SA, Huang M-T: Anti-tumor activity of the crude saponins obtained from asparagus. Cancer letters 1996, 104(1):31-36.

33. Padmaja R, Arun P, Prashanth D, Deepak M, Amit A, Anjana M: Brine shrimp lethality bioassay of selected Indian medicinal plants. Fitoterapia 2002, 73(6):508-510.

34. Tiwari P, Kumar B, Kaur M, Kaur G, Kaur H: Phytochemical screening and extraction: a review. Int Pharm Sci 2011, 1(1):98-106.

35. Iqbal H, Moneeb URK, Riaz U, Zia M, Naeem K, Farhat AK, Zahoor U, Sajjad $\mathrm{H}$ : Phytochemicals screening and antimicrobial activities of selected medicinal plants of Khyberpakhtunkhwa Pakistan. Afr J Pharm Pharmacol 2011, 5(6):746-750.

36. Meriga B, Mopuri R, Muralikrishna T: Insecticidal, antimicrobial and antioxidant activities of bulb extracts of Allium sativum. Asian Pac J Trop Med 2012, 5(5):391-395.

37. Turker AU, Camper N: Biological activity of common mullein, a medicinal plant. J Ethnopharmacol 2002, 82(2):117-125.

38. Meyer B, Ferrigni N, Putnam J, Jacobsen L, Nichols D, McLaughlin J: Brine shrimp: a convenient general bioassay for active plant constituents. Planta medica 1982, 45(05):31-34.

\section{doi:10.1186/0717-6287-47-57}

Cite this article as: Zeb et al: Phytochemical and toxicological investigations of crude methanolic extracts, subsequent fractions and crude saponins of Isodon rugosus. Biological Research 2014 47:57.

\section{Submit your next manuscript to BioMed Central and take full advantage of:}

- Convenient online submission

- Thorough peer review

- No space constraints or color figure charges

- Immediate publication on acceptance

- Inclusion in PubMed, CAS, Scopus and Google Scholar

- Research which is freely available for redistribution

Submit your manuscript at www.biomedcentral.com/submit
() Biomed Central 